\title{
Tegangan Sisa pada Bahan Model Fotoelastis Epoxi Resin karena Perlakuan Termal
}

\author{
Gatut Yudoyono, ${ }^{*}$ Hery Kurniawan, dan Rinaldi W \\ Labobatorium Optik dan Optoelektronika (LoopIts) \\ Jurusan Fisika-FMIPA, Institut Teknologi Sepuluh Nopember \\ Kampus ITS Sukolilo,Surabaya 60111
}

\begin{abstract}
Intisari
Telah dilakukan karakterisasi termal terhadap bahan polimer epoxi resin sebagai bahan model fotoelastis. Hasil sintesa resin epoxi dan hardener dengan perbandingan volume 100:2 memberikan sifat elastis yang berbeda ketika masing-masing diberi perlakuan termal dengan melihat pola frinji fotoelastis terutama parameter tegangan sisa. Variasi pembebanan dan perlakuan termal pada sampel fotoelastis epoxi resin menunjukkan bahwa pada temperatur pemanasan $90^{\circ} \mathrm{C}-100^{\circ} \mathrm{C}$ memberikan kualitas bahan fotoelastis yang paling optimal bila ditinjau dari ketiadaan tegangan sisa yang masih ada pada sampel setelah pembebanan dihilangkan.
\end{abstract}

KATA KUNCI: fotoelastisitas, epoxi resins, tegangan sisa, karakterisasi model fotoelastis

\section{PENDAHULUAN}

Polimer epoxi resin sebagai bahan model fotoelastis telah banyak digunakan [1-3]. Hal ini dikarenakan polimer epoxi resin lebih mudah dibuat sebagai model fotoelastis [4-6], baik model dua dimensi maupun tiga dimensi. Dari beberapa model fotoelastis yang telah dibuat, terdapat sejumlah model yang belum berada dalam kondisi yang optimal, yakni masih dapat berubah sewaktu diberi pembebanan pada waktu yang lain. Untuk mengoptimalisasi karakteristik mekanik epoxi resin sebagai bahan model fotoelastis perlu dilakukan penelitian lebih lanjut dengan memberikan beberapa perlakuan terhadap bahan model fotoelastis tersebut [7-9].

Secara umum metode fotoelastisitas adalah salah satu metode yang digunakan untuk menganalisis apa yang terjadi pada suatu bahan apabila bahan tersebut dikenai gaya luar. Salah satunya adalah menganalisis distribusi tegangan pada bahan tersebut. Dalam analisa model, perlu diketahui sifat dan karakteristik bahan model tersebut, karena karakteristik bahan fotoelastis ini cukup berpengaruh terhadap distribusi tegangan. Karakteristik bahan fotoelastis tersebut akan mempengaruhi penjalaran cahaya polarisasi dalam bentuk pola frinji yang nantinya pola frinji yang terbentuk akan dapat digunakan untuk menganalisis distribusi tegangan dalam model fotoelastis.

Faktor yang cukup penting dalam analisis fotoelastisitas adalah pemilihan bahan fotoelastis yang akan digunakan untuk membuat model fotoelastis. Syarat agar dapat digunakan sebagai bahan fotoelastis adalah bahan yang memiliki sifat optik isotropis, transparan, serta elastis. Jika bahan tersebut diberi gaya luar, maka di dalam bahan tersebut akan terjadi perubahan sifat optik. Sedangkan apabila gaya luar tersebut dihilangkan, maka bahan akan kembali seperti keadaan awal

*E-MAIL: gyudoyono@physics.its.ac.id seperti sebelum diberi gaya luar.

Makalah ini melaporkan hasil penelitian tentang peningkatan kualitas bahan sampel model fotoelastis polimer epoxi resin. Karakterisasi bahan polimer epoxi resin hasil sintesis dilakukan dengan memberi perlakuan termal untuk meningkatkan parameter elastisitas bahan. Pada penelitian sebelumnya ditunjukkan bahwa polimer epoxi resin sebagai bahan fotoelastis yang tidak diberi perlakuan termal memberikan tegangan sisa pada model setelah pembebanan dihilangkan.

\section{METODOLOGI}

\section{A. Preparasi Sampel}

Bahan yang digunakan sebagai sampel pada penelitian ini adalah epoxi resin hasil sintesa resin epoxi dan hardener dengan perbandingan komposisi 100:2. Pada penelitian sebelumnya [3] telah didapatkan nilai frinji bahan resin epoxi yang tidak mengalami perlakuan termal dengan komposisi di atas sebesar 5.013,857 N/m. Besaran ini sangat bermanfaat saat digunakan untuk menentukan distribusi tegangan pada sampel dengan melihat orde frinji. Pada preparasi sampel dilakukan dua tahap proses, yaitu pemotongan dan penghalusan sampel. Model fotoelastisitas dibuat atau dipotong dari lembaran epoxi resin hasil sintesa, sehingga menjadi bentuk model sederhana yakni bentuk balok. Dibuat 4 (empat) sampel balok dengan ukuran $(2,3 \times 1 \times 2,3) \mathrm{cm}^{3}$. Pemotongan harus dilakukan dengan perlahan dan sebaiknya sering ditetesi dengan menggunakan air, karena hal ini dapat mereduksi kenaikan temperatur ketika bahan model di gergaji. Diharapkan dengan proses pendinginan ini dapat mengurangi bahkan menghilangkan residual of stress yang timbul saat proses pemotongan.

Tahap berikutnya adalah penghalusan permukaan sampel dengan tujuan untuk mengurangi kekasaran permukaan sehingga menjadi permukaan yang tidak difuse atau kasar. 
Penghalusan sampel diawali dengan cara menggosok model yang telah di potong dari cetakan dengan ampelas yang mempunyai ukuran kekasaran ampelas 240, 280, 320, 360, 400, 500, 1000, 1200, dan 2000. Proses penghalusan dilakukan berturut-turut dari ampelas yang paling kasar hingga yang terhalus. Dalam melakukan pengampelasan seperti halnya dalam penggergajian sebaiknya dilakukan pendinginan dengan menggunakan cairan (air) yang diteteskan pada permukaan sampel.

Setelah dilakukan proses penghalusan sehingga didapatkan model sesuai dengan yang diharapkan (transparan) dengan ukuran $(1,75 \times 0,7 \times 1,75) \mathrm{cm}^{3}$. Apabila belum didapatkan model yang sesuai atau transparan, maka model dapat di poles lagi dengan menggunakan autosol. Fungsi autosol di sini adalah sebagai zat yang dapat mereduksi zat pengotor yang terdapat pada permukaan bahan model yang nantinya akan dilewati oleh sinar polikromatik.

\section{B. Perlakuan Termal}

Proses perlakuan termal di berikan dengan pemanasan terhadap sampel. Ke-empat sampel yang telah dibuat diberi 6 (enam) perlakuan termal, yakni:

\section{Sampel 1}

Perlakuan I : Tanpa pemanasan (dengan suhu kamar)

2. Sampel 2

Perlakuan II : Pemanasan dengan temperatur $90^{\circ} \mathrm{C}$

3. Sampel 3

- Perlakuan III : Pemanasan dengan temperatur $100^{\circ} \mathrm{C}$

- Perlakuan IV : pemanasan dengan temperatur $150^{\circ} \mathrm{C}$ (setelah perlakuan III)

- Perlakuan V : pemanasan dengan temperatur $200^{\circ} \mathrm{C}$ (setelah perlakuan IV)

4. Sampel 4

Perlakuan VI : pemanasan dengan temperatur $250^{\circ} \mathrm{C}$

Pemberian perlakuan termal tersebut dengan menggunakan furnace (Naber Industrieofenbav D-2804 Lilienthal / Bremen) dan untuk temperatur diukur dengan menggunakan termometer digital (Tipe 2575) dengan lamanya waktu pemanasan selama 10 menit. Setelah perlakuan termal, masing-masing didinginkan secara perlahan hingga mencapai suhu kamar dengan cara mendinginkan sampel didalam furnace yang telah dimatikan tegangan listriknya.

\section{Eksperimen}

Setelah ke-empat macam sampel (bahan fotoelastis) mendapatkan 6 (enam) perlakuan termal seperti diuraikan di atas, maka proses selanjutnya mengamati distribusi tegangan dan

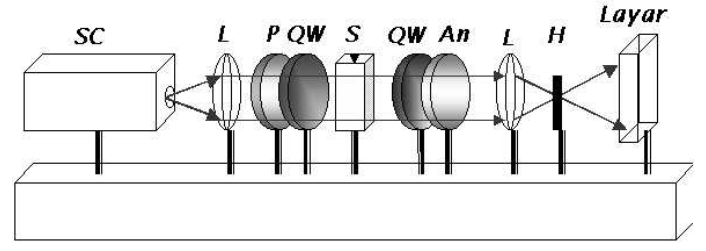

Gambar 1: Skema eksperimen polariskop lingkaran

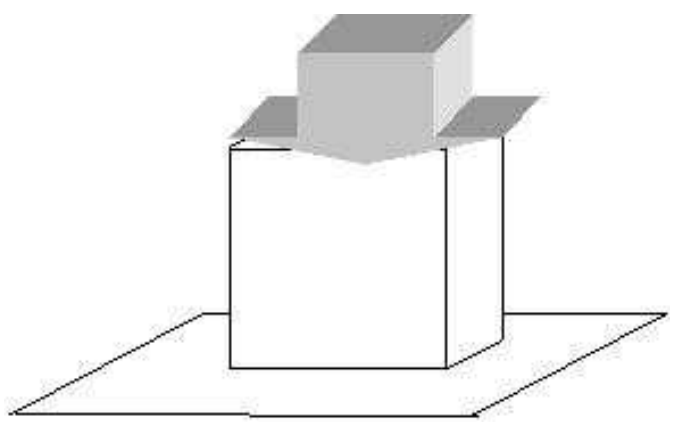

Gambar 2: Pembebanan

tegangan yang tersisa dengan menggunakan peralatan fotoelastisitas/polariskop lingkaran (skema peralatan seperti ditunjukkan Gambar 1). Sumber polikromatik (SC) berupa lampu pijar $30 \mathrm{~W}, 12 \mathrm{~V}$; lensa pengkolimasi (L) untuk mengkolimasi berkas cahaya, sehingga mengurangi penyimpangan yang terjadi pada $\lambda / 4$ [10]; polarisator (P) dan analisator (An); keping $\lambda / 4(\mathrm{QW})$; lensa pemfokus $100 \mathrm{~mm}(\mathrm{~L})$; pin hole $(\mathrm{H})$; layar dan kamera. Polariskop lingkaran disusun untuk menghasilkan frinji isokromatik pola gelap.

Sampel yang dingin setelah mendapatkan perlakuan termal diamati frinji isokromatik pola medan gelap. Pada sampel diberikan tegangan mekanik secara merata pada seluruh permukaan dengan gaya luar sebesar $50 \mathrm{~N}$, dengan arah penekanan seperti ditunjukkan dalam Gambar 2. Pembebanan dilakukan terhadap sampel selama 5 (lima) menit dan setelah itu gaya luar dilepaskan. Tegangan yang masih tersisa dan perubahan yang terjadi pada model diamati dan direkam setiap 3 (tiga) menit sampai pada menit ke 24 dengan menggunakan kamera digital (Nikon COOLPIX 3100 3,2 Megapixels). Selanjutnya dilakukan proses yang sama dengan besar pembebanan gaya luar sebesar $100 \mathrm{~N}$ dan $150 \mathrm{~N}$. Proses yang sama juga dilakukan terhadap model dengan perlakuan II, III, IV, V, dan VI.

\section{HASIL DAN PEMBAHASAN}

Dalam menentukan karakteristik bahan polimer resin epoxi sebagai bahan model fotoelastis akibat pengaruh temperatur, maka digunakan polariskop lingkaran dengan cahaya polikromatik untuk mendapatkan pola frinji isokromatik yang akan diamati perubahannya. Dari pengamatan yang dilakukan dalam penelitian ini diperoleh pola frinji yang mencerminkan perubahan struktur yang terjadi pada bahan polimer 
epoxi resin, waktu yang diperlukan bahan untuk kembali ke keadaan asal, dan tegangan sisa pada sampel, serta perlakuan terbaik untuk mendapatkan sampel yang paling baik sebagai bahan sampel fotoelastisitas. Perubahan struktur yang terjadi dapat diamati dengan membandingkan sampel ketika belum diberi perlakuan termal dengan setelah di beri perlakuan dengan variasi temperatur. Perubahan struktur juga dapat diamati dengan melihat perubahan yang terjadi setelah sampel di beri variasi temperatur dan variasi tegangan luar.

Waktu yang diperlukan untuk kembali ke keadaan awal hanya dibatasi selama 24 menit. Tegangan tersisa dalam sampel hanya terletak pada salah satu sisi dari sampel. Tegangan sisa adalah tegangan yang masih tersisa pada sampel ketika gaya luar sudah dilepaskan dan sifat dari tegangan sisa ini adalah permanen (tetap) tersimpan dalam suatu bahan. Penentuan kualitas bahan sampel yang paling baik ditentukan dengan melihat atau mengamati sampel yang memerlukan waktu paling sedikit untuk kembali ke asal setelah tegangan luar dilepaskan. Hal ini berdasarkan pada sifat bahan fotoelastis, bahwa suatu bahan dikatakan semakin baik sifat-sifat fotoelastisnya apabila pengaruh tegangan pada suatu bahan semakin cepat berkurang.

\section{A. Hasil Pengamatan}

Hasil pengamatan dari penelitian yang dilakukan berdasarkan pada variasi temperatur dan tegangan. Fotoelastogram frinji isokromatik sampel epoxi resin baik yang belum mendapat perlakuan termal maupun yang telah dipanaskan, dengan pembebanan yang bervariasi dapat dilihat pada Tabel 1, Tabel 2, dan Tabel 3. Fotoelastogram yang ditampilkan dibatasi sampai waktu tertentu, karena setelah waktu tersebut pola isokromatik yang masih ada mengalami perubahan yang sangat perlahan.

\section{B. Analisis dan Pembahasan}

Sesuatu yang cukup menarik perhatian pada fotoelastogram hasil pengamatan adalah adanya bagian sisi sebelah atas dari gambar (pola frinji) yang terbentuk setelah diberi variasi temperatur seperti ditunjukkan pada Tabel 4. Pola seperti ini sama dengan gambar fotoelastogram saat sampel belum mendapatkan pembebanan dari luar. Fotoelastogram yang terbentuk seperti Tabel 4 memerlukan waktu yang sangat lama sehingga tidak tampak pada fotoelastogram Tabel 1, Tabel 2, dan Tabel 3. Semakin besar tegangan luar yang diberikan maka semakin lama waktu yang diperlukan untuk kembali ke-keadaan awal. Bagian tersebut adalah tegangan sisa sesuai dengan definisinya yaitu tegangan yang masih tersimpan dalam suatu material meskipun tegangan tersebut telah dihilangkan atau dilepaskan dan hal ini berkaitan erat dengan perlakuan mekanik dan termal terhadap bahan. Kemungkinan besar tegangan sisa tersebut terjadi dikarenakan perlakuan penggergajian terhadap bahan yang mengakibatkan terjadi kenaikan temperatur secara tidak langsung. Hal ini memungkinkan terjadinya residual of stress dalam material tersebut. Sehingga bagian tersebut tidak dapat dilakukan pengujian lebih lanjut. Adanya peningkatan temperatur secara tidak langsung tersebut dapat dihilangkan atau direduksi dengan pemberian cairan (air) yang dapat menurunkan atau mengurangi peningkatan temperatur pada saat penggergajian (perlakuan mekanik). Cara lain untuk menghilangkan tegangan sisa adalah dengan melakukan pencampuran antara resin dan hardener secara lebih homogen. Hal ini bisa dilakukan dengan cara pengadukan yang lebih lama atau pencetakan di tempat cetakan yang lebih kecil.

Karakteristik elastisitas suatu bahan fotoelastis secara umum dapat ditinjau dari waktu yang diperlukan suatu bahan untuk mengurangi atau menghilangkan tegangan yang masih tersisa di dalam bahan tersebut ketika tegangan atau gaya luar telah dilepaskan. Semakin cepat suatu bahan dapat menghilangkan tegangan yang masih tersisa tersebut, semakin baik kualitas suatu bahan. Hilangnya tegangan yang masih tersisa dapat diketahui melalui ada tidaknya pola frinji dalam sampel tersebut. Selain itu juga bisa dilihat melalui tidak adanya lagi perubahan warna dari hasil yang tampak pada layar.

Pengamatan pola frinji yang terdapat pada Tabel 1 terlihat bahwa waktu berkurang-nya tegangan yang masih tersisa pada bahan sampel dengan pemberian tegangan atau gaya luar sebesar $50 \mathrm{~N}$, sampel bahan perlakuan pemanasan pada temperatur $200^{\circ} \mathrm{C}$ lebih cepat daripada bahan sampel dengan pemanasan pada temperatur $150^{\circ} \mathrm{C}, 100^{\circ} \mathrm{C}$, maupun $90^{\circ} \mathrm{C}$. Demikian juga dari pola frinji isokromatik yang ditunjukkan Tabel 3 terlihat bahwa dari ketiga sampel dengan pemberian tegangan sebesar $150 \mathrm{~N}$ masih ada tegangan yang tersisa. Jika dibandingkan ketiganya, maka pada bahan tanpa pemberian pemanasan memerlukan waktu yang lebih lama untuk menghilangkan tegangan yang tersisa dibanding bahan dengan pemberian variasi temperatur. Pada bahan dengan variasi temperatur, semakin rendah temperatur pemanasan, maka semakin lama waktu yang diperlukan untuk menghilangkan tegangan yang tersisa tersebut.

Perlakuan variasi temperatur dapat diketahui bahwa semakin besar pemanasan yang diberikan pada suatu benda maka semakin cepat tegangan yang masih tersisa tersebut hilang. Tetapi hal ini tidak dapat dilihat hanya dari segi cepat tidaknya suatu bahan dapat menghilangkan tegangan tersebut. Tetapi juga harus dilihat dari segi bahan yang digunakan mengingat suatu bahan memiliki titik tahan panas tertentu. Sifat khas bahan polimer adalah sangat berubah oleh perubahan temperatur. Hal ini disebabkan apabila temperatur berubah, pergerakan molekul karena termal akan mengubah kumpulan molekul atau merubah struktur (terutama struktur yang berdimensi besar). Selanjutnya kemungkinan besar akibat panas yang diberikan, oksigen dan air bersama-sama, memancing reaksi kimia pada molekul-molekul sehingga terjadilah depolimerisasi, oksidasi, hidrolisa yang lebih hebat terjadi pada temperatur tinggi. Keadaan tersebut akan mempengaruhi sifat-sifat mekanik, listrik dan kimia [11].

Dalam penelitian ini hanya dibatasi pada sifat-sifat termalnya yang akan membahas mengenai titik tahan panas dari bahan polimer resin epoxi. Kalau temperatur polimer naik, pergerakan molekul menjadi aktif ke titik transisi, yang menyebabkan modulus elastik dan kekerasannya rendah, sedang- 
Tabel I: Fotoelastogram frinji isokromatik dengan variasi temperatur pada $\mathrm{F}=50 \mathrm{~N}$.

\begin{tabular}{|c|c|c|c|c|c|c|}
\hline $\begin{array}{l}\text { Waktu } \\
\text { (menit) }\end{array}$ & $\begin{array}{c}\text { Tanpa } \\
\text { pemanasan }\end{array}$ & $\mathrm{T}=90^{\circ} \mathrm{C}$ & $\mathrm{T}=100^{\circ} \mathrm{C}$ & $\mathrm{T}=150^{\circ} \mathrm{C}$ & $\mathrm{T}=200^{\circ} \mathrm{C}$ & $\mathrm{T}=250^{\circ} \mathrm{C}$ \\
\hline Terbebani & & & & & & \\
\hline $0 * *$ & & & & & & \\
\hline $6^{* * *}$ & & & & & & \\
\hline
\end{tabular}

*) Sampel terbebani selama 5 menit, **) Beban dihilangkan dan gambar diambil setelah 0 dan 6 menit

Tabel II: Fotoelastogram frinji isokromatik dengan variasi temperatur pada $\mathrm{F}=100 \mathrm{~N}$.

\begin{tabular}{|c|c|c|c|c|c|c|}
\hline $\begin{array}{l}\text { Waktu } \\
\text { (menit) }\end{array}$ & $\begin{array}{c}\text { Tанч a } \\
\text { pemanasan }\end{array}$ & $\mathrm{T}=90^{\circ} \mathrm{C}$ & $\mathrm{T}=100^{\circ} \mathrm{C}$ & $T=150^{\circ} \mathrm{C}$ & $\mathrm{T}=200^{\circ} \mathrm{C}$ & $\mathrm{T}=250^{\circ} \mathrm{C}$ \\
\hline Terbeb ani & & & & & & \\
\hline $0^{* \star}$ & & & & & & \\
\hline $9^{*+}$ & & & & & & \\
\hline
\end{tabular}

*) Sampel terbebani selama 5 menit, **) Beban dihilangkan dan gambar diambil setelah 0 dan 9 menit

Tabel III: Fotoelastogram frinji isokromatik dengan variasi temperatur pada $\mathrm{F}=150 \mathrm{~N}$.

\begin{tabular}{|c|c|c|c|c|c|c|}
\hline $\begin{array}{l}\text { Waktu } \\
\text { (menit) }\end{array}$ & $\begin{array}{c}\text { Tалфа } \\
\text { pemanasan }\end{array}$ & $\mathrm{T}=90^{\circ} \mathrm{C}$ & $\mathrm{T}=100^{\circ} \mathrm{C}$ & $\mathrm{T}=150^{\circ} \mathrm{C}$ & $\mathrm{T}=200^{\circ} \mathrm{C}$ & $\mathrm{T}=250^{\circ} \mathrm{C}$ \\
\hline Terbeb ani & & & & & & \\
\hline $0^{* *}$ & & & & & & \\
\hline $24^{\star *}$ & & & & & & \\
\hline
\end{tabular}

*) Sampel terbebani selama 5 menit, **) Beban dihilangkan dan gambar diambil setelah 0 dan 24 menit 
Tabel IV: Tegangan sisa pada model

\begin{tabular}{|c|c|c|c|c|c|c|}
\hline Perblanan & $\begin{array}{c}\text { Tanpa } \\
\text { pemanasan }\end{array}$ & $\mathrm{T}=90^{\circ} \mathrm{C}$ & $\mathrm{T}=100^{\circ} \mathrm{C}$ & $\mathrm{T}=150^{\circ} \mathrm{C}$ & $\mathrm{T}=\mathbf{2 0 0 ^ { \circ } \mathrm { C }}$ & $\mathrm{T}=250^{\circ} \mathrm{C}$ \\
\hline $\begin{array}{c}\text { Pola golop } \\
\text { tanpa } \\
\text { pembebanan }\end{array}$ & & & Shench & rense & & $4=$ \\
\hline
\end{tabular}

kan tegangan patahnya kecil. Kalau temperatur melewati titik transisi, bahan amorf (termoplastik) seperti karet menjadi lunak, dan selain perubahan pada sifat-sifat di atas modulus elastiknya juga tiba-tiba berubah.

Sangat sukar untuk menelaah ketahanan panas bahan polimer pada temperatur tinggi, sebab banyak sekali faktorfaktor yang akan memberikan pengaruh tertentu seperti keadaan lingkungan, bentuk bahan, macam dan jumlah pengisi, adanya bahan penyetabil dan seterusnya. Lamanya waktu berada pada temperatur tinggi juga merupakan persoalan. Dalam penelitian ini variasi temperatur adalah $90^{\circ} \mathrm{C}, 100^{\circ} \mathrm{C}$, $150^{\circ} \mathrm{C}, 200^{\circ} \mathrm{C}$, dan $250^{\circ} \mathrm{C}$ dengan lamanya waktu pemanasan adalah 10 menit dan lamanya waktu pendinginan adalah 12 jam. Hal ini dikarenakan apabila bahan (sampel) diambil secara langsung setelah pemanasan selesai akan dapat menyebabkan kerusakan (cacat) pada material karena perubahan temperatur yang mendadak.

Fotoelastogram dalam Tabel 1, Tabel 2, dan Tabel 3 terlihat bahwa terjadi perubahan struktur frinji yang mencolok pada saat pemanasan $150^{\circ} \mathrm{C}$ dan $200^{\circ} \mathrm{C}$, tetapi tidak demikian untuk pemanasan dengan temperatur $90^{\circ} \mathrm{C}-100^{\circ} \mathrm{C}$. Sehingga bisa dikatakan bahwa titik tahan panas dari bahan polimer epoxi resin dengan pemberian hardener dengan perbandingan resin-hardener adalah $100: 2$ adalah $90^{\circ} \mathrm{C}-100^{\circ} \mathrm{C}$. Hal ini tidak terpaut jauh dengan data ketahanan panas epoxi resin (tanpa pengisi), yaitu sebesar $90^{\circ} \mathrm{C}-130^{\circ} \mathrm{C}$ [11].

Fenomena lain yang menarik dari Tabel 1, Tabel 2, Tabel 3, dan Tabel 4 terlihat pada temperatur $250^{\circ} \mathrm{C}$ pada bahan sampel sudah tidak terjadi perubahan yang berarti, dan pola frinji hanya terlihat ketika bahan sampel ditekan dengan tegangan sebesar $100 \mathrm{~N}$ dan $150 \mathrm{~N}$. Dan pola frinji hanya muncul pada saat di tekan. Ketika tegangan dilepaskan, pola frinji sudah tidak terlihat lagi. Hal ini dikarenakan bahan sampel ketika dipanasi pada temperatur $250^{\circ} \mathrm{C}$ telah terjadi kerusakan pada bahan tersebut, baik sifat mekanik maupun sifat elastisnya. Kerusakan tersebut juga terlihat dari keadaan fisik dari bahan sampel tersebut, seperti terlihat pada Gambar 3.d.

Sedangkan bahan sampel dengan pemberian temperatur $200^{\circ} \mathrm{C}$ (Gambar 3.c) masih dapat memberikan pola frinji isokromatik pada layar. Meskipun telah terjadi perubahan warna pada sampel, tetapi sampel fotoelastis tersebut masih dapat memunculkan pola warna frinji isokromatik seperti ditunjukkan pada Tabel 1, Tabel 2, dan Tabel 3, sehingga dapat dikatakan bahwa bahan masih dapat dipergunakan dengan pemanasan hingga sebesar $200^{\circ} \mathrm{C}$.
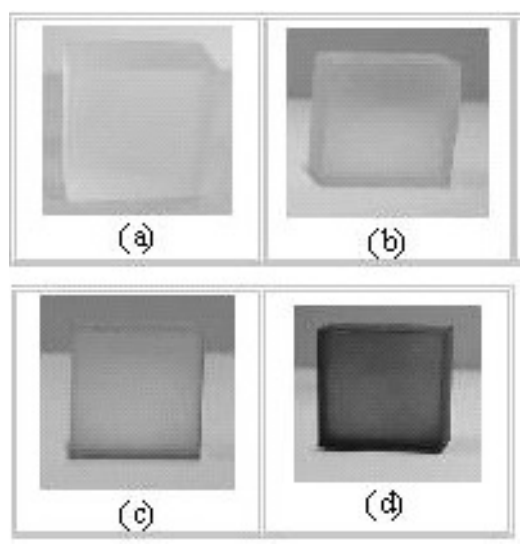

Gambar 3: Foto sampel fotoelastis sebelum dan setelah diberi perlakuan termal,(a) sebelum dipanasi, (b) temperatur $90^{\circ} \mathrm{C}$, (c) $200^{\circ} \mathrm{C}$ (d) $250^{\circ} \mathrm{C}$

\section{SIMPULAN}

Pemberian perlakuan termal pada bahan sampel fotoelastisitas epoxi resin hasil sintesa dengan perbandingan 100:2 yang optimal adalah antara $90^{\circ} \mathrm{C}-100^{\circ} \mathrm{C}$ karena pada perlakuan temperatur tersebut, tegangan yang tersisa relatif cepat berkurang dan susunan strukturnya polimernya masih berada pada kondisi yang baik. Sedangkan jika dipanaskan di atas temperatur $200^{\circ} \mathrm{C}$ sampel akan mengalami kerusakan. Sifat elastisitas bahan sampel fotoelastisitas epoxi resin hasil sintesa tanpa perlakuan termal (mentah) lebih buruk dibanding bahan dengan perlakuan pemanasan hingga temperatur berkisar antara $90^{\circ} \mathrm{C}-100^{\circ} \mathrm{C}$.
[1] E.Bormashenko,et.al., J. of Optics A :Pure and Applied Optics, July, Vol.3, p. 299 (2000)

[2] J.V. Champion, S.J Dodd and G.C Stevens, Journal of Physics D: Applied Physics, 14 December, Vol.25, 1821 (1992)

[3] G.Yudoyono, Prosiding Seminar Fisika dan Aplikasinya 2002,
Fisika, MIPA-ITS, Surabaya, Vol.2, hal. 211- 215 (2002)

[4] J.W. Dally, and W.F.Riley, Experimental Stress Analysis, Mc Graw Hill Book Company, New York (1991)

[5] B.Ellis, Chemistry and Technology of Epoxy Resins, Blackie Academics and Professional, London (1993) 
[6] W.C.Wang, and T.L.Chen, Optical Engineering, Vol.31, No.1,p.144-55 (1992)

[7] F.A.Khayyat, and P. Stanley, J. of Physics D: Applied Physics, June, Vol.11, p. 1237 (1978)

[8] V.Griseri,et.al., J.of Physics D: Applied Physics, August, Vol. 34, p.2534 (2001)

[9] G.Dickinson, and M.L.Sanderson, Measurement Science and
Technology, July, Vol.5, p. 869 (1994)

[10] G.Yudoyono, A.Y.Rohedi, Jurnal MIPA, Unair, Vol.7, No.2, Agustus,hal. 71-76 (2002)

[11] S.Saito, (terj. Surdia, T.), Pengetahuan Bahan Teknik, Cetakan Kedua, PT. Pradnya Paramita, Jakarta (1992) 